\title{
First report of the photosynthetic dinoflagellate Heterocapsa minima in the Pacific Ocean: morphological and genetic characterizations and the nationwide distribution in Korea
}

\author{
Sung Yeon Lee ${ }^{1}$, Hae Jin Jeong ${ }^{1,2, *}$, Ji Eun Kwon ${ }^{1}$, Ji Hyun You ${ }^{1}$, So Jin Kim ${ }^{1}$, Jin Hee Ok ${ }^{1}$, \\ Hee Chang Kang ${ }^{1}$ and Jae Yeon Park ${ }^{2}$
}

${ }^{1}$ School of Earth and Environmental Sciences, College of Natural Sciences, Seoul National University, Seoul 08826, Korea

${ }^{2}$ Advanced Institutes of Convergence Technology, Suwon 16229, Korea

\begin{abstract}
The genus Heterocapsa is one of the major dinoflagellate groups, with some of its species having worldwide distributions. However, prior to the present study, the phototrophic species Heterocapsa minima has been reported only from the northeast Atlantic Ocean. Recently, H. minima was found in the Korean waters, and a clonal culture was established. This culture was used to examine the morphology of the Korean strain H. minima HMMJ1604 through light and scanning electron microscopy, as well as for its genetic characterization. Furthermore, to determine the nationwide distribution of H. minima in Korea, its abundance was quantified in the waters of 28 stations in all four seasons in 2016-2018 using the quantitative real-time polymerase chain reaction method. The overall morphology of H. minima HMMJ1604 was very similar to that of the Irish strain H. minima JK2. However, the Korean strain had five pores around the pore plate, whereas the Irish strain had six pores. When properly aligned, the sequences of the large subunit and internal transcribed spacer regions of the ribosomal DNA of the Korean strain were identical to those of the Irish strain. This species was detected in the waters of 26 out of 28 stations, but its abundance was greater than 1.0 cells $\mathrm{mL}^{-1}$ at 8 stations. The highest abundance of $H$. minima was 44.4 cells $\mathrm{mL}^{-1}$. Although this species was found in all seasons, its abundance was greater than 1.0 cells $\mathrm{mL}^{-1}$ when the water temperature and salinity were $10.9-25.0^{\circ} \mathrm{C}$ and $17.5-34.1$, respectively. To the best knowledge, the present study reported for the first time that H. minima lives in the Pacific Ocean and is widely distributed in the Korean waters.
\end{abstract}

Key Words: DNA; Peridiniales; qPCR; salinity; specific primer; taxonomy; temperature

\section{INTRODUCTION}

Phototrophic dinoflagellates are ubiquitous and one of the major components in marine ecosystem (Anderson et al. 2012, Glibert et al. 2012, Jeong et al. 2013). In last three decades, many phototrophic dinoflagellates that had been thought to be exclusively autotrophic have been revealed to be mixotrophic (Burkholder et al. 2008,
Jeong et al. 2010, 2015, Stoecker et al. 2017). Thus, they play diverse roles as primary producers, predators, and prey in marine food webs (Tillmann 2004, Jeong et al. 2005, 2018, Flynn et al. 2013, Johnson 2015, Stoecker et al. 2017). Furthermore, many phototrophic dinoflagellate species often form red tides or harmful algal blooms
(7) \$ This is an Open Access article distributed under the terms of the Creative Commons Attribution Non-Commercial License (http://creativecommons.org/licenses/by-nc/3.0/) which permits unrestricted non-commercial use, distribution, and reproduction in any medium, provided the original work is properly cited.
Received December 28, 2018, Accepted February 28, 2019

* Corresponding Author

E-mail: hjjeong@snu.ac.kr

Tel: +82-2-880-6746, Fax: +82-2-874-9695 
causing large-scale mortality of fin-fish, shellfish, marine mammals, and sea birds (Scholin et al. 2000, Shumway et al. 2003, Place et al. 2012, Adolf et al. 2015, Menden-Deuer and Montalbano 2015). Therefore, the eco-physiology of a phototrophic dinoflagellate, its roles in marine food webs, and its distribution are critical concerns to scientists and aquaculture farmers (Hansen 2011, Carstensen et al. 2015, Jeong et al. 2017, Lee et al. 2017a, Lim et al. 2017). Prior to exploring these topics, this dinoflagellate should be well identified.

The genus Heterocapsa was first established by Stein (1883), and until now, approximately 20 species have been described in the genus (Iwataki 2008, Tillmann et al. 2017, Guiry and Guiry 2019). All species in this genus have theca on the surface with a plate formula of Po, cp, x, 5', 3a, 7", 6c, 5s, 5"', 2"'" (Iwataki 2008, Iwataki et al. 2009). Furthermore, they have distinct organic threedimensional body scales and one pyrenoid with a starch sheath (Iwataki 2008). This genus has received attention because some species cause red tides or harmful algal blooms (Hansen 1989, Horiguchi 1995, Matsuyama et al. 1995, 1997, Nagai et al. 1996, Matsuyama 1999, Iwataki et al. 2002, Iwataki 2008, Salas et al. 2014); Heterocapsa circularisquama Horiguchi, Heterocapsa rotundata (Lochmann) Hansen, and Heterocapsa triquetra (Ehrenberg) F. Stein often form red tides causing shellfish mortalities. Of these species, $H$. rotundata and $H$. triquetra are known to have worldwide distributions (Lohmann 1908, Paulsen 1908, Lebour 1925, Grontved and Seidenfaden 1938, Braarud and Pappas 1951, Balech 1988, Iwataki 2008, Carstensen et al. 2015, Tillmann et al. 2017). Heterocapsa minima Pomroy was first described by Pomroy (1989) based on cells collected from the Celtic Sea in 1982-1983. Although the abundance of H. minima in the fixed samples collected from the Bay of Biscay, Spain was reported, the morphology or genetic characterization of H. minima cells were not reported (Iriarte et al. 2003). Later, Salas et al. (2014) reported the detailed morphology and genetic characterization of H. minima strain JK2 that was originally collected from the Irish Sea.

Heterocapsa minima has the epitheca significantly larger than the hypotheca, in a manner similar to Heterocapsa arctica Horiguchi, Heterocapsa lanceolata Iwataki \& Fukuyo, and H. rotundata (Pomroy 1989, Salas et al. 2014). However, H. minima, the smallest species in the genus, is smaller than $H$. arctica, $H$. lanceolata, and $H$. rotundata (Iwataki 2008, Salas et al. 2014). Furthermore, H. minima has an extra plate-like structure that acts like a hinge joining the $\mathrm{x}$-plate to the cover plate, unlike the other Heterocapsa species (Salas et al. 2014). Moreover, $H$. minima has rounded triangular-shaped body scales with a small central hole on the basal plate. The genus Heterocapsa has body scales unique in shape and structure (Hansen 1995, Salas et al. 2014).

In 2016, small dinoflagellate cells were isolated from the waters of Mijo Port, South Sea of Korea, and a clonal culture was setup. Using this culture, we carefully examined the morphology of this dinoflagellate using light and scanning electron microscopy, and obtained the sequences of the internal transcribed spacer (ITS), and large subunit (LSU) ribosomal (r) DNA. Based on the morphological and genetic analyses, this dinoflagellate was identified to be $H$. minima. Prior to the present study, this species was found only in the northeast Atlantic Ocean (Pomroy 1989, Iriarte et al. 2003, Salas et al. 2014). Thus, we investigated morphological and genetic characterizations of the Korean strain and compared the morphological characterization with the descriptions given by Pomroy (1989) and Salas et al. (2014). We also compared the genetic characterization of the Korean strain with that of H. minima strain JK2, which is the only stain for which rDNA sequence is available. Furthermore, to determine the nationwide distribution of H. minima in Korea, its abundance was quantified in the waters of 28 stations, located in the East, West, and South Sea of Korea, and in the Jeju Island, Korea in all four seasons from January 2016 to October 2018, using the quantitative real-time polymerase chain reaction (qPCR) method and newly designed $H$. minima specific primer-probe sets. The results of the present study provide a basis for understanding the morphological and genetic characterizations of the H. minima strains and its global and nationwide distributions.

\section{MATERIALS AND METHODS}

\section{Collection and culture of the Korean strain of Heterocapsa minima}

The Korean strain of H. minima (HMMJ1604) was isolated from the surface water in Mijo Port, South Sea of Korea $\left(34^{\circ} 71^{\prime} \mathrm{N}, 128^{\circ} 04^{\prime} \mathrm{E}\right)$ in April 2016 when water temperature and salinity were $12.9^{\circ} \mathrm{C}$ and 30.3 , respectively (Kwon 2018). A clonal culture of this species was established by two serial single-cell isolations. Dense cultures of H. minima HMMJ1604 were transferred to new 250$\mathrm{mL}$ polycarbonate (PC) bottle (approximately 200,000 cells $\mathrm{mL}^{-1}$ ) every 1-2 weeks. The bottles were filled to capacity with fresh $\mathrm{f} / 2$-si seawater medium, capped, and 
placed on a shelf at $20^{\circ} \mathrm{C}$ with an irradiance of $20 \mu \mathrm{mol}$ photons $\mathrm{m}^{-2} \mathrm{~s}^{-1}$ provided by cool white fluorescent lights, with a $14: 10 \mathrm{~h}$ light : dark cycle. The culture in exponential growth phase was then used for genetic and morphological analyses.

\section{Morphology}

The overall shape and size of motile cells of H. minima HMMJ1604 in cover glass-bottom dish (confocal dish; SPL, Pocheon, Korea) were measured using an image analysis system for processing images taken with a digital camera connected to an inverted microscope (Zeiss-AxioCam MRc5; Carl Zeiss, Göttingen, Germany) at magnifications of $\times 1,000$. Detailed morphological characterizations, such as the shape and size of each plate, and the number of plates, were analyzed using scanning electron microscopy (SEM). For SEM observation, approximately $5 \mathrm{~mL}$ of a dense culture of $\mathrm{H}$. minima HMMJ1604 was fixed for $10 \mathrm{~min}$ in paraformaldehyde at a final concentration of $2 \%(\mathrm{v} / \mathrm{v})$ in filtered seawater (FSW). The fixed cells were filtered through $3-\mu \mathrm{m}$ polycarbonate membrane filter $(25 \mathrm{~mm}$ diameter, Whatman, Floreham Park, NJ, USA) without additional suction and washed serially with 50\% FSW and distilled water. Then, filters with collected cells were dehydrated in an ethanol series $(10,30$, $50,70,90$, and $100 \%$ ) for 2 min followed by two changes in $100 \%$ ethanol for $10 \mathrm{~min}$. Subsequently, the filters were critical point dried (CPD 300; Bal-Tec, Balzers, Liechtenstein), mounted on a stub, sputter-coated with platinum, and examined at $2 \mathrm{kV}$ using AURIGA CrossBeam (Carl Zeiss).

\section{Nucleic acid extraction, PCR amplification, se- quencing, and phylogenetic analyses}

For PCR amplification, the nucleic acids were extracted from 10 to $15 \mathrm{~mL}$ of a dense culture of H. minima
HMMJ1604 using the AccuPrep Genomic DNA Extraction Kit (Bioneer, Daejeon, Korea), according to the manufacturer's instructions. The PCR amplification of the LSU, and ITS region of rDNA was performed using the primers Euk1209F (Giovannoni et al. 1988), ITSR2 (Litaker et al. 2003), D1RF (Scholin et al. 1994), and LSUB (Litaker et al. 2003) (Table 1). Next, Solg f-Taq DNA Polymerase (SolGent Co., Daejeon, Korea) was used according to the manufacturer's instructions to amplify the DNA. The DNA was amplified in a Mastercycler ep gradient thermal cycler (Eppendorf, Hamburg, Germany) using the following cycling conditions: $3 \mathrm{~min}$ at $94^{\circ} \mathrm{C}$ pre-denaturation, followed by 35 cycles of $1 \mathrm{~min}$ at $94^{\circ} \mathrm{C}, 1 \mathrm{~min}$ at the annealing temperature, and $2 \mathrm{~min}$ at $72^{\circ} \mathrm{C}$, with a final extension of $5 \mathrm{~min}$ at $72^{\circ} \mathrm{C}$. The obtained PCR products were purified using AccuPrep PCR Purification Kit (Bioneer) according to manufacturer's instructions. Subsequently, the purified products were sent to the Genome Research Facility at School of Biological Science, Seoul National University, Korea, and sequenced with an ABI PRISM 3700 DNA Analyzer (Applied Biosystems, Foster City, CA, USA). The obtained sequences were aligned and manually edited using ContigExpress (Infomax, Frederick, MD, USA). The edited sequences were deposited in National Center for Biotechnology Information (NCBI) GenBank as a single contig (accession No. MK483261).

For performing the phylogenetic analysis of the LSU and ITS regions of H. minima HMMJ1604, each sequence was aligned using MEGA v.4 (Tamura et al. 2007), with the sequences of Prorocentrum species as an outgroup and other Heterocapsa species obtained from NCBI database and recently published studies (Salas et al. 2014). The maximum likelihood (ML) analyses were conducted using the RAxML 7.0.4 program with a GTRGAMMA model (Stamatakis 2006). Further, 200 independent tree inferences were used to identify the best tree. The ML bootstrap values were determined using 1,000 replicates. Bayesian analyses were conducted using MrBayes v.3.1

Table 1. Oligonucleotide primers used to amplify the SSU, ITS1, 5.8S, ITS2, and LSU regions of rDNA and the species-specific primers and TaqMan probe used to quantify the abundance of Heterocapsa minima using qPCR method

\begin{tabular}{lllll}
\hline \multicolumn{1}{c}{ Name } & \multicolumn{2}{c}{ Primer region } & \multicolumn{1}{c}{$\mathbf{5}^{\prime} \mathbf{- 3}^{\prime}$} & Reference \\
\hline Euk1209F & Forward & SSU-ITS & GGGCATCACAGACCTG & Giovannoni et al. (1988) \\
ITSR2 & Reverse & ITS & TCCCTGTTCATTCGCCATTAC & Litaker et al. (2003) \\
D1RF & Forward & LSU & ACCCGGTGAATTTAAGCATA & Scholin et al. (1994) \\
LSUB & Reverse & LSU & ACGAACGATTTGCACGTCAG & Litaker et al. (2003) \\
Hminima_F & Forward & ITS & TCATATCGAAGCCTTCATGC & In this study \\
Hminima_R & Reverse & ITS & CACTTAAGAAAGAATACTGGAGC & In this study \\
Hminima_P & Probe & ITS & [FAM] GGGAGTCTTTGAGCACGCTTTTGTGTG [BHQ1] & In this study \\
\hline
\end{tabular}

SSU, small subunit; ITS, internal transcribed spacer; LSU, large subunit. 


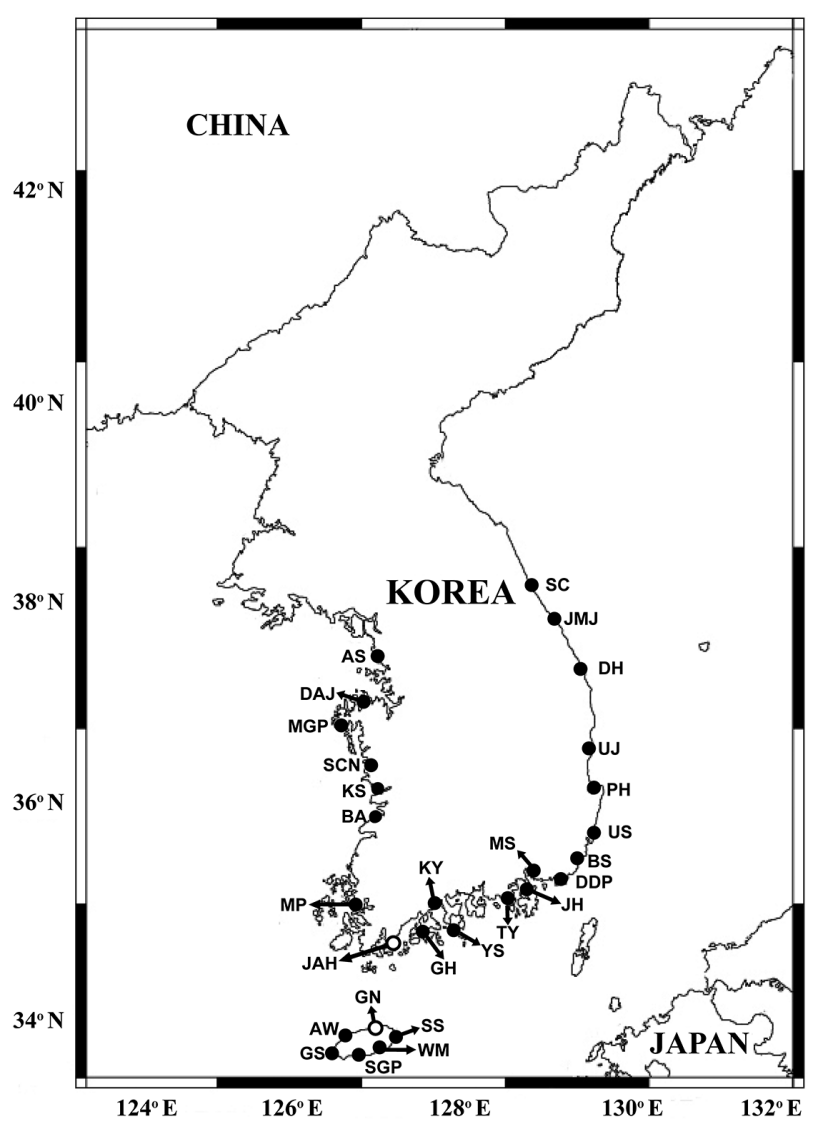

Fig. 1. Map of the sampling stations of the study area in Korea. The circles indicate the sampling stations. The closed circles indicate the stations at which Heterocapsa minima cells were detected, whereas the open circles indicate the stations at which $\mathrm{H}$. minima cells were not detected. SC, Sokcho; JMJ, Jumunjin; DH, Donghae; UJ, Uljin; PH, Pohang; US, Ulsan; BS, Busan; DDP, Dadaepo; MS, Masan; JH, Jinhae; TY, Tongyoung; YS, Yeosu; KY, Kwangyang; GH, Goheung JAH, Jangheung; AS, Ansan; DAJ, Dangjin; MGP, Mageompo; SCN, Seocheon; KS, Kunsan; BA, Buan; MP, Mokpo; AW, Aewol; GS, Gosan; SGP, Seogwipo; WM, Wimi; SS, Seongsan; GN, Gimnyeong.

(Ronquist and Huelsenbeck 2003) in the default GTR + $\mathrm{G}+\mathrm{I}$ model to determine the best available model for the data from each region. For all sequence regions, four independent Markov Chain Monte Carlo runs were performed simultaneously until the average standard deviation of split frequencies dropped below 0.01 . The trees were sampled every 1,000 generations. To ensure likelihood convergence, the first 1,000 trees were discarded as burn-in.

\section{Design of TaqMan probe and primer set}

Using the program MEGA v.4, the ITS sequences of the H. minima HMMJ1604 obtained from PCR amplification were aligned with the ITS rDNA sequence of the Irish strain of H. minima and related dinoflagellates available from the GenBank. Manual searches of the alignments were conducted to determine the unique sequences and to develop a H. minima-specific qPCR assay. The sequences for the primer-probe set were selected from the regions that were conserved within $H$. minima strains, but allowed discrimination with other dinoflagellates. The primer and probe sequences of the target species were analyzed with Primer 3 (Whitehead Institute and Howard Hughes Medical Institute, MD) and Oligo Calc: Oligonucleotide Properties Calculator (Kibbe 2007) for optimal melting temperature and secondary structure. Subsequently, the primers and probe were synthesized by Bioneer. The probe was dual-labeled with the fluorescent dyes, FAM and BHQ1 (Bioneer), at the $5^{\prime}$ and $3^{\prime}$ ends, respectively (Table 1).

\section{Quantification of the abundance of Heterocapsa minima in the Korean waters}

Using a clean bucket, water samples were collected from the surface of 28 stations located in the East, West, and South Sea of Korea, and Jeju Island, Korea, in January, March, July, October, and December 2016, 2017 and January, March, July, and October 2018 (Fig. 1).

For qPCR, 50-300 $\mathrm{mL}$ of the collected water sample from each station at each interval were filtered through 25-mm GF/C filter (Whatman). The filter was loosely rolled and placed into a $1.5-\mathrm{mL}$ tube and frozen under $-20^{\circ} \mathrm{C}$ until transfer to the laboratory. The DNA from cells on the filter of each sample was extracted as described above.

\section{Generating standard curve and qPCR amplifica- tion}

To obtain the standard curve, DNA was extracted from a dense culture of H. minima HMMJ1604, targeting $1,000,000$ cells in the final elution volume of $100 \mu \mathrm{L}$, using the identical DNA extraction method mentioned above. The extracted DNA was then serially diluted by adding predetermined volumes of deionized sterile water (DDW) (Bioneer) to the $1.5-\mathrm{mL}$ tubes, to ultimately prepare 7 different DNA concentrations, targeting 100, 10, 1, 0.1, 0.01, 0.001 , and $0.0001 \%$ of the originally extracted DNA. Subsequently, the DNA samples were stored at $-20^{\circ} \mathrm{C}$ in the freezer and a qPCR amplification was conducted within a day. The qPCR assays for the determination of the standard curve were performed using the following steps 

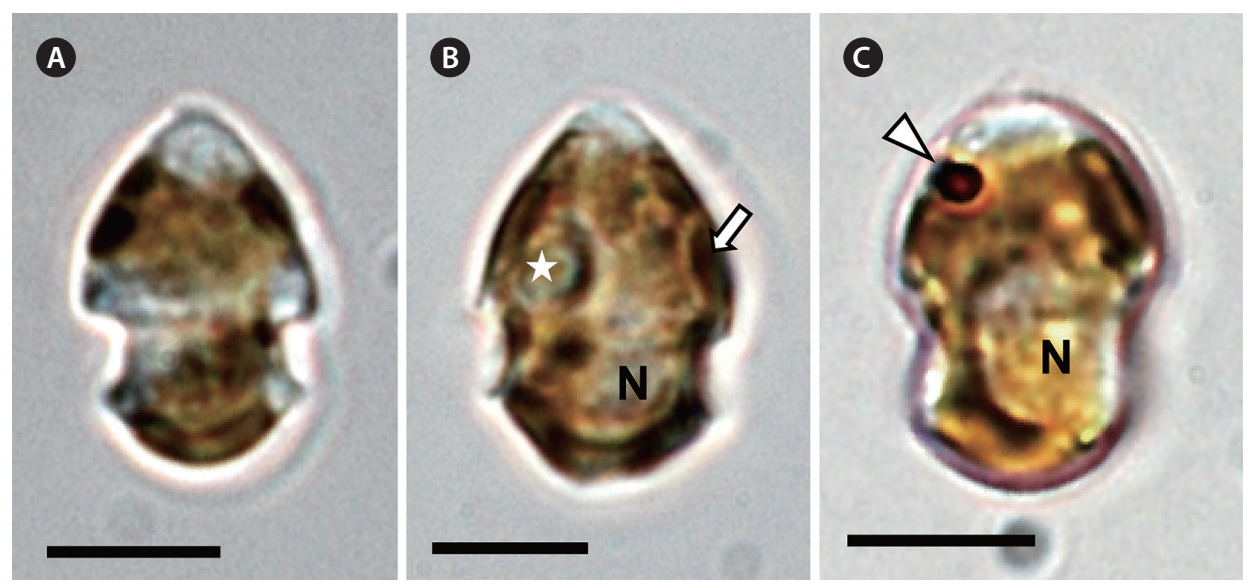

Fig. 2. Micrographs of living cells in the clonal culture of Heterocapsa minima HMMJ1604, taken by light microscopy. (A) H. minima cell showing the conical epitheca and rounded hypotheca with a deeply excavated cingulum. (B) A pyrenoid with starch sheath (asterisk) is positioned in the epitheca, while the large ellipsoid nucleus $(\mathrm{N})$ is positioned in the central part of cell. The chloroplast lobe of a single chloroplast is positioned near the surface of a cell (arrow). (C) A large nucleus ( $\mathrm{N}$ ) and a small red accumulation body (arrowhead). Scale bars represent: A-C, $5 \mu \mathrm{m}$. [Colour figure can be viewed at http://www.e-algae.org].

modified from Lee et al. (2017b): $1 \mu \mathrm{L}$ of DNA template, $0.2 \mu \mathrm{M}$ of primers (forward and reverse) and $0.15 \mu \mathrm{M}$ of probe (final concentrations), and $5 \mu \mathrm{L}$ of qPCRBIO Probe Separate-ROX (Genepole, Gwangmyeong, Korea) were combined and DDW was added to each sample, resulting in the total final volume of $10 \mu \mathrm{L}$. The qPCR analyses were performed using Rotor-Gene Q (Qiagen, Hilden, Germany) under following thermal cycling conditions: 3 min at $95^{\circ} \mathrm{C}$, followed by 45 cycles of $10 \mathrm{~s}$ at $95^{\circ} \mathrm{C}$, and 40 $s$ at $58^{\circ} \mathrm{C}$.

The aforementioned qPCR assay conditions were used to determine the concentration of H. minima in field samples. The DNA from each sample was amplified four times to ensure the accuracy of results. The sample using DDW as the template was used as a negative control, whereas the one used to construct a standard curve was used as positive and standard control.

\section{RESULTS}

\section{Morphology of the Korean strain of Heterocapsa minima}

Motile cells of $H$. minima HMMJ1604 have the conical epitheca over rounded hypotheca with a deeply excavated cingulum (Fig. 2A). The epitheca was larger than the hypotheca (Fig. 2). The large and ellipsoid nucleus was positioned in the central part of the cell (Fig. 2B \& C).
Near the cell surface, the chloroplast lobe from a single chloroplast was present (Fig. 2B). In addition, a single large pyrenoid surrounded by a starch sheath was constantly present in the epitheca (Fig. 2B). Furthermore, a small red accumulation body was found in the epitheca (Fig. 2C). The length and width of motile cells $(\mathrm{n}=30)$ were 7.0-11.2 $\mu \mathrm{m}$ (mean \pm standard deviation: $9.5 \pm 2.1$ ) and 5.4-9.0 $\mu \mathrm{m}(6.9 \pm 1.8)$, respectively, and the length-towidth ratio was 1.1-1.6 (Table 2).

The SEM observation showed that the cell length and width of $H$. minima HMMJ1604 ( $=14)$ were slightly shrunk to 7.4-9.3 (8.4 \pm 0.2$) \mu \mathrm{m}$ and 5.2-6.9 (6.2 \pm 0.2$)$ $\mu \mathrm{m}$, respectively, and the length-to-width ratio was 0.9 $1.8(1.3 \pm 0.1)$ (Table 2). The epitheca had the apical pore complex (APC), five apical plates, three intercalary plates, and seven precingular plates (Figs $3 \& 4$ ). The APC comprised an apical pore plate (Po), a cover plate (cp), canal plate $(\mathrm{x})$, and a hinge plate (?) connecting $\mathrm{cp}$ and $\mathrm{x}$ (Figs 3F, G \& 4C). The Po plate of all the cells observed $(n=13)$ had five thecal pores arranged around the Po plate (Fig. $3 \mathrm{~F})$. The $\mathrm{x}$ plate touched 1 ' and 5 ' apical plate and displaced to the right side of the cell (Figs 3A, F, G \& 4C). The $1^{\prime}, 2^{\prime}$, and $5^{\prime}$ apical plates were larger than the $3^{\prime}$ and $4^{\prime}$ apical plates (Figs $3 \mathrm{G} \& 4 \mathrm{C}$ ). The precingular plates were mostly pentagonal except for the $4 "$ and $7 "$ plate (Figs 3AD, G \& 4A-C). Furthermore, the cingulum consisting of 6 rectangular-shaped cingulum plates $(n=14)$ was displaced by $0.10-0.20$ times the cell length and 0.13-0.29 times the cell width. 
The hypotheca of H. minima HMMJ1604 had five postcingular plates and two antapical plates (Table 2, Figs $3 \mathrm{H} \& 4 \mathrm{D})$. The 2 "', 4 "', and 5"' plates were quadrangular, whereas the $1 "$ ' and 3 "' plates were pentagonal. The antapical plates were both pentagonal. In addition, it had five sulcal plates (Table 2); anterior sulcal plate (as), left anterior sulcal plate (las), left posterior sulcal plate (lps), right sulcal plate (rs), and posterior sulcal plate (ps) (Figs $3 \mathrm{~A}, \mathrm{E} \& 4 \mathrm{~A})$. Scales were only present in the 1 "' postcingular plate and in the antapical plates including 1 "'" and 2"'" (Fig. 3H). Conclusively, the plate formula based on Kofoidian series of $H$. minima HMMJ1604 was Po, cp, x, 5', 3a, 7", 6c, 5s, 5"', and 2"'" (Table 2, Figs 3 \& 4).

\section{Molecular characterization of the Korean strain of Heterocapsa minima}

The sequence of the ITS regions and LSU rDNA of H. minima HMMJ1604 was identical to that of the Irish strain of H. minima JK2, the only strain of which LSU and ITS sequences have been reported. However, the LSU rDNA sequence of H. minima HMMJ1604 was 22-62 bp $(=3.7-8.7 \%)$ different from that of Heterocapsa triquetra, the type species of the genus, and also $38 \mathrm{bp}(4.3 \%)$ and 35-61 bp (4.9-8.5\%) different from Heterocapsa arctica Horiguchi and Heterocapsa rotundata, respectively, the closest species (Table 3). Furthermore, the ITS rDNA

Table 2. Comparison of the morphology of the Korean (HMMJ1604) and Irish strains (JK2) of Heterocapsa minima and cells of H. minima collected from the Celtic Sea based on specimens observed by light (LM) and scanning electron microscopy (SEM)

\begin{tabular}{|c|c|c|c|}
\hline & $\begin{array}{c}\text { H.minima } \\
\text { (HMMJ1604, Korea) }\end{array}$ & $\begin{array}{l}\text { H. minima } \\
\text { (JK2, Ireland) }\end{array}$ & $\begin{array}{l}\text { H. minima } \\
\text { (Celtic sea) }\end{array}$ \\
\hline AP length $(\mu \mathrm{m}, \mathrm{LM})$ & $7.0-11.2(9.5 \pm 2.1)$ & $10-13.0(11.8 \pm 0.6)$ & NA \\
\hline Cell width $(\mu \mathrm{m}, \mathrm{LM})$ & $5.4-9.0(6.9 \pm 1.8)$ & $6.9-9.1(8.1 \pm 0.5)$ & NA \\
\hline Length-to-width ratio (LM) & $1.1-1.6$ & NA & NA \\
\hline AP length $(\mu \mathrm{m}, \mathrm{SEM})$ & $7.4-9.3(8.4 \pm 0.2)$ & $7.3-12.9(10.2 \pm 1.1)$ & $8.7( \pm 1.3)$ \\
\hline Cell width $(\mu \mathrm{m}, \mathrm{SEM})$ & $5.2-6.9(6.2 \pm 0.2)$ & $5.7-9.0(7.1 \pm 0.6)$ & $6.1( \pm 0.7)$ \\
\hline Length-to-width ratio (SEM) & $0.9-1.8(1.3 \pm 0.1)$ & NA & 1.43 \\
\hline Shape of epitheca & Conical & Rounded or pointed & Conical \\
\hline Shape of hypotheca & Rounded & Rounded, sometimes pointed & Rounded \\
\hline $\begin{array}{l}\text { Epitheca and Hypotheca size } \\
\text { comparison }\end{array}$ & Epitheca larger & Epitheca larger & Epitheca larger \\
\hline Apical pore plate (Po) & $\mathrm{Y}$ & $\mathrm{Y}$ & $\mathrm{Y}$ \\
\hline Pores around the Po plate & $5(n=13)$ & 6 & NA \\
\hline Cover plate $(\mathrm{cp})$ & $\mathrm{Y}$ & $\mathrm{Y}$ & $\mathrm{Y}$ \\
\hline Canal plate $(\mathrm{x})$ & $\mathrm{Y}$ & $\mathrm{Y}$ & $\mathrm{Y}$ ? \\
\hline Hinge plate (?) & $\mathrm{Y}$ & $\mathrm{Y}$ & NA \\
\hline Plate Formulae & $\begin{array}{l}\text { Po, cp, x, 5', 3a, 7", 6c, 5s, } \\
5^{\prime \prime \prime}, 2^{\prime \prime \prime \prime}\end{array}$ & Po, cp, x, 5', 3a, 7", 6c, 5s, 5"', 2"'" & $\begin{array}{l}\text { Pp (= Po), cp, 5', 3a, 7", 6c, } \\
5 \mathrm{~s}, 5^{\prime \prime \prime}, 2^{\prime \prime \prime \prime}\end{array}$ \\
\hline Reference & This study & Salas et al. (2014) & Pomroy (1989) \\
\hline
\end{tabular}

Values in the parentheses are mean \pm standard deviation.

AP, anteroposterior; NA, not available.

Table 3. Comparison of the sequences of the large subunit rDNA of the Korean strain of Heterocapsa minima and the other strain of $H$. minima and other species in the Heterocapsa genus

\begin{tabular}{|c|c|c|c|c|c|c|c|c|c|}
\hline & $\begin{array}{c}\text { H. minima } \\
\text { JK2 (Ireland) } \\
\text { KF031312 }\end{array}$ & $\begin{array}{l}\text { H. arctica } \\
\text { AY571372 }\end{array}$ & H.triquetra ${ }^{\mathrm{a}}$ & $\begin{array}{c}\text { H.pseudo- } \\
\text { triquetra } \\
\text { MF423367 }\end{array}$ & $\begin{array}{c}\text { H. rotundata } \\
\text { AF260400, } \\
\text { EU165312, } \\
\text { KF240778 }\end{array}$ & $\begin{array}{c}\text { H. niei } \\
\text { JQ247713, } \\
\text { AY916548 }\end{array}$ & $\begin{array}{c}\text { H.pygmaea } \\
\text { EU165306, } \\
\text { FJ939577 }\end{array}$ & $\begin{array}{c}\text { H. circular- } \\
\text { isquama } \\
\text { AB049709 }\end{array}$ & $\begin{array}{c}\text { Heterocapsa } \\
\text { sp. }{ }^{\text {b }}\end{array}$ \\
\hline $\begin{array}{l}\text { H. minima } \\
\text { HMMJ1604 } \\
\text { (Korea) }\end{array}$ & $\begin{array}{c}0 \\
0 \\
(0.0)\end{array}$ & $\begin{array}{c}38 \\
(4.3)\end{array}$ & $\begin{array}{c}22-62 \\
(3.7-8.7)\end{array}$ & $\begin{array}{c}61 \\
(8.5)\end{array}$ & $\begin{array}{c}35-61 \\
(4.9-8.5)\end{array}$ & $\begin{array}{c}46-51 \\
(5.7-8.5)\end{array}$ & $\begin{array}{c}60-62 \\
(8.2-8.8)\end{array}$ & $\begin{array}{c}69 \\
(9.5)\end{array}$ & $\begin{array}{c}34-62 \\
(5.7-9.4)\end{array}$ \\
\hline
\end{tabular}

The numbers are base pairs different from each other. The numbers in parenthesis indicate dissimilarity (\%) including gaps.

${ }^{\mathrm{a}}$ H. triquetra accession No.: AF260401, EF613355, EU165307, HQ902267, KT389965, MF423346-MF423349, MF423356-MF423363.

${ }^{\mathrm{b}}$ Heterocapsa sp. accession No.: AF260399, AY371082, EU165274, JN020164, JN119844, KT371446, KT860562, KX853175, KX853177, KX853178, KX853187, MF471315-MF471319. 

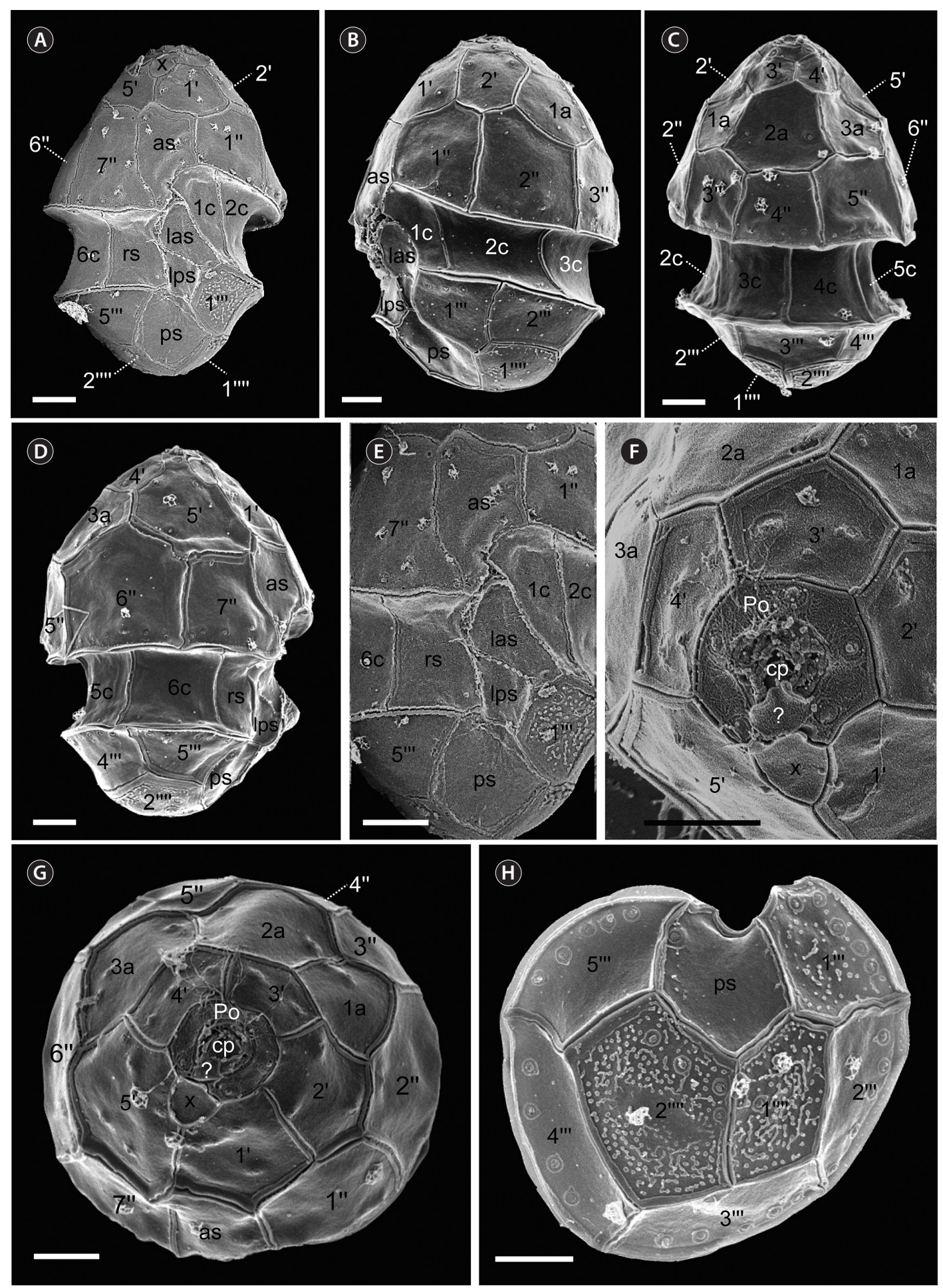

Fig. 3. Micrographs of vegetative cells of Heterocapsa minima HMMJ1604 taken by scanning electron microscopy. (A) Ventral view showing the epitheca, cingulum (c), sulcus (as, las, rs, Ips, and ps), and hypotheca. (B) Ventral-left lateral view showing the epitheca, cingulum (c), sulcus (as, las, Ips, and ps), and hypotheca. (C) Dorsal view showing the epitheca, cingulum (c), and hypotheca. (D) Ventral-right lateral view showing the epitheca, cingulum (c), sulcus (as, rs, Ips, and ps), and hypotheca. (E) Enlarged from (A) showing detailed view of sulcus (as, las, rs, Ips, and ps). (F) Apical pore complex (Po, cp, ?, x) and thecal pores arranged in the Po plate. (G) Apical view showing the apical pore complex (Po, cp, ?, $x$ ), epitheca and sulcus (as). (H) Antapical view showing the hypotheca, and sulcus (ps). as, anterior sulcal; las, left anterior sulcal; rs, right sulcal; lps, left posterior sulcal; ps, posterior sulcal; Po, apical pore plate; $c p$, cover plate; $x$, canal plate; ?, the extra structure acting as a hinge or connection. Scale bars represent: $\mathrm{A}-\mathrm{H}, 1 \mu \mathrm{m}$. 

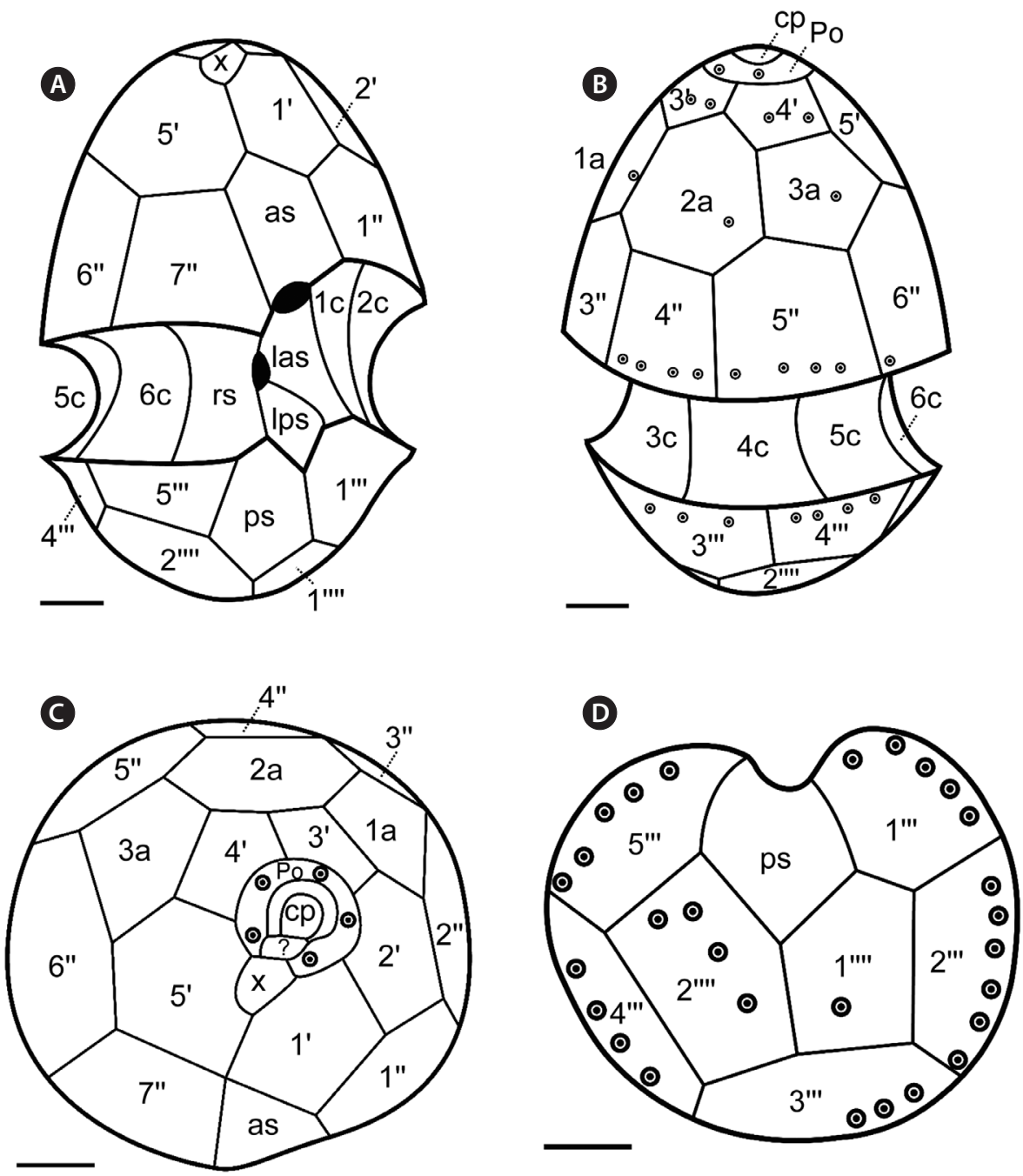

Fig. 4. Drawings of vegetative cells of Heterocapsa minima HMMJ1604, showing the external morphology. (A) Ventral view. (B) Dorsal view. (C) Apical view. (D) Antapical view. Scale bars represent: A-D, $1 \mu \mathrm{m}$. as, anterior sulcal; las, left anterior sulcal; rs, right sulcal; Ips, left posterior sulcal; ps, posterior sulcal; Po, apical pore plate; $c p$, cover plate; $x$, canal plate; ?, the extra structure acting as a hinge or connection.

Table 4. Comparison of the sequences of the internal transcribed spacer rDNA of the Korean strain of Heterocapsa minima and the other strain of H. minima and other species in the Heterocapsa genus

\begin{tabular}{|c|c|c|c|c|c|c|c|c|c|c|}
\hline & $\begin{array}{l}\text { H. minima } \\
\text { JK2 (Ire- } \\
\text { land) } \\
\text { KF031311 }\end{array}$ & $\begin{array}{c}\text { H. arctica } \\
\text { AB084095, } \\
\text { JQ972677 }\end{array}$ & $\begin{array}{c}\text { H.tri- } \\
\text { quetra }^{\mathrm{a}}\end{array}$ & $\begin{array}{l}\text { H.huensis } \\
\text { AB445394 }\end{array}$ & $\begin{array}{l}\text { H. illdefina } \\
\text { JQ972687 }\end{array}$ & $\begin{array}{c}\text { H.ro- } \\
\text { tundata } \\
\text { KY095027, } \\
\text { KY095061, } \\
\text { KF240777 }\end{array}$ & $\begin{array}{c}\text { H. niei } \\
\text { FJ823556, } \\
\text { FJ823557, } \\
\text { JN020158 }\end{array}$ & $\begin{array}{c}\text { H. pygmaea } \\
\text { AB084093, } \\
\text { AB084094, } \\
\text { FJ823558 }\end{array}$ & $\begin{array}{c}\text { H. circular- } \\
\text { isquama } \\
\text { AB084089, } \\
\text { AB049711 }\end{array}$ & $\begin{array}{c}\text { Hetero- } \\
\text { capsa } \\
\text { sp. }^{\mathrm{b}}\end{array}$ \\
\hline $\begin{array}{l}\text { H. minima } \\
\text { HMMJ1604 } \\
\text { (Korea) }\end{array}$ & $\begin{array}{c}0 \\
(0.0)\end{array}$ & $\begin{array}{c}60-71 \\
(10.0-10.9)\end{array}$ & $\begin{array}{c}54-117 \\
(12.0-17.4)\end{array}$ & $\begin{array}{c}45 \\
(11.0)\end{array}$ & $\begin{array}{c}67 \\
(15.1)\end{array}$ & $\begin{array}{c}79-83 \\
(11.3-12.4)\end{array}$ & $\begin{array}{c}92-105 \\
(14.2-16.9)\end{array}$ & $\begin{array}{c}90-109 \\
(16.2-16.9)\end{array}$ & $\begin{array}{c}94-125 \\
(17.0-18.0)\end{array}$ & $\begin{array}{c}31 \\
(4.6)\end{array}$ \\
\hline
\end{tabular}

The numbers are base pairs different from each other. The numbers in parenthesis indicate dissimilarity (\%) including gaps.

${ }^{\mathrm{a}}$ H. triquetra accession No.: AB084101, AF208249, AF352363, AF352364, AF527816, HQ902267, JQ972678, KT389965, KX465107, KY095018, KY095023, KY095034, KY095036, MF423346-MF423349, MF423351-MF423355, MF423364-MF423366.

${ }^{\mathrm{b}}$ Heterocapsa sp. accession No.: AB084096-AB084100, AY499509, FJ823559, JQ972681, JQ991005, JX661019, JX661020, KM067396, KX853191, KX853194, MF471310-MF471314. 


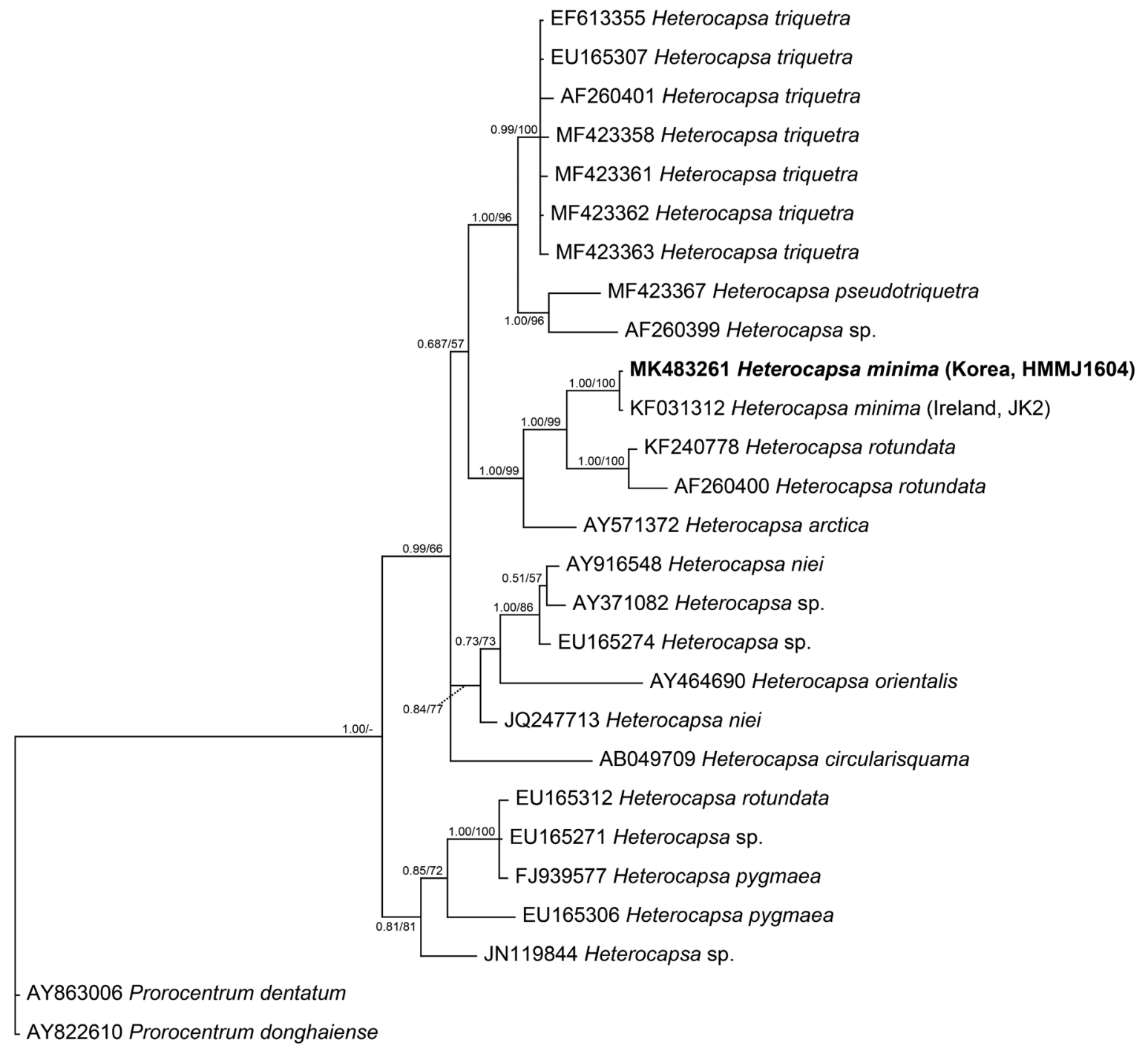

0.1

Fig. 5. Consensus Bayesian tree based on 952 bp aligned positions of the large subunit regions, using the GTR $+G+I$ model and the dinoflagellates Prorocentrum dentatum and Prorocentrum donghaiense as an outgroup taxa. The numbers above the branches indicate the Bayesian posterior probability (left) and maximum likelihood bootstrap values (right). Posterior probabilities $\geq 0.5$ are shown.

sequences of $H$. minima HMMJ1604 was 54-117 bp (= $12.0-17.4 \%)$ different from 25 strains of H. triquetra, 60-71 bp (10.0-10.9\%) from H. arctica and 79-83 bp (11.3$12.4 \%$ ) from $H$. rotundata (Table 4 ).

In the phylogenetic tree based on the LSU rDNA sequences of Heterocapsa species, H. minima HMMJ1604 formed a clade with the Irish strain of H. minima JK2 (Fig. 5). Moreover, in the phylogenetic tree based on the ITS rDNA sequences, H. minima HMMJ1604 also formed a clade with $H$. minima JK2, but this clade was clearly divergent from the clades containing the other Heterocapsa species (Fig. 6).

\section{Distribution of Heterocapsa minima in Korean waters}

When the qPCR method was used, H. minima was detected in the waters of 26 stations out of 28 stations, but the abundance of $H$. minima was greater than 0.1 cells $\mathrm{mL}^{-1}$ at 15 stations and that greater than 1.0 cells $\mathrm{mL}^{-1}$ at 8 stations (Tables $5 \& 6$, Fig. 1). The highest abundance of H. minima, 44.4 cells $\mathrm{mL}^{-1}$, was obtained in Buan in July 2017, and the second highest abundance, 24.8 cells $\mathrm{mL}^{-1}$, was obtained in Ulsan in July 2017 (Table 6). The highest abundance in the winter (January / December), spring 


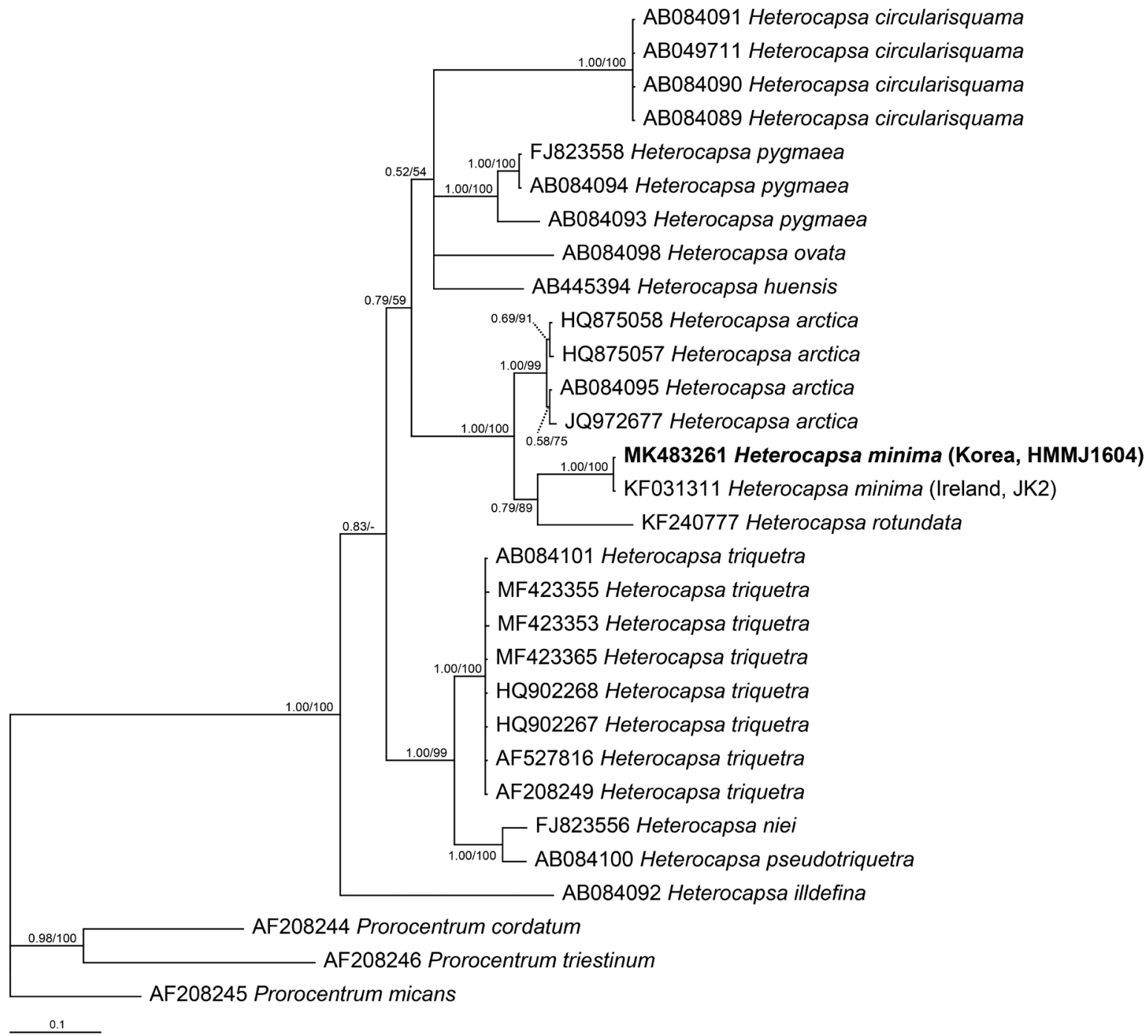

Fig. 6. Consensus Bayesian tree based on 661 bp aligned positions of the internal transcribed spacer regions, using the GTR $+\mathrm{G}+\mathrm{I}$ model and the dinoflagellates Prorocentrum cordatum ( $=$ P. minimum), Prorocentrum micans, and Prorocentrum triestinum as an outgroup taxa. The numbers above the branches indicate the Bayesian posterior probability (left) and maximum likelihood bootstrap values (right). Posterior probabilities $\geq 0.5$ are shown.

(March), summer (July), and fall (October) was 23.0, <0.1, 44.4 , and 0.6 cells $\mathrm{mL}^{-1}$, respectively (Table 6 ).

The cells of H. minima were found in all seasons. The water temperature and salinity at all stations in the study period were $0.2-28.0^{\circ} \mathrm{C}$ and $0.1-35.6$, respectively (Table 5). However, the water temperature and salinity at the stations where $H$. minima were detected were $0.2-27.1^{\circ} \mathrm{C}$ and $13.3-34.4$, respectively. Furthermore, the abundance of $H$. minima was higher than 0.1 cells $\mathrm{mL}^{-1}$ in July, September, and December 2016, July 2017, and July 2018 when the water temperature and salinity were 10.9$25.4^{\circ} \mathrm{C}$ and 17.5-34.1, respectively (Tables $5 \& 6$ ). Moreover, the abundance of H. minima was higher than 1.0 cells $\mathrm{mL}^{-1}$ in July and December 2016, July 2017, and July 2018 when the water temperature and salinity were 10.9$25.0^{\circ} \mathrm{C}$ and $17.5-34.1$, respectively (Tables $5 \& 6$ ).

\section{DISCUSSION}

To the best of our knowledge, the present study reports for the first time that H. minima lives in the Pacific Ocean, and is widely distributed in the Korean waters. This study extends the distribution of $H$. minima from the Atlantic Ocean to the Pacific Ocean. 
Table 5. The maximum and minimum temperature and salinity at all sampling stations at which water samples were collected (ASW), and at the stations at which Heterocapsa minima was detected (SHD)

\begin{tabular}{|c|c|c|c|c|c|c|c|c|}
\hline \multirow{2}{*}{ Station } & \multicolumn{4}{|c|}{ Temperature $\left({ }^{\circ} \mathrm{C}\right)$} & \multicolumn{4}{|c|}{ Salinity } \\
\hline & Min-ASW & Max-ASW & Min-SHD & Max-SHD & Min-ASW & Max-ASW & Min-SHD & Max-SHD \\
\hline Sokcho & 5.2 & 21.6 & 19.0 & 19.7 & 31.2 & 34.3 & 31.2 & 33.4 \\
\hline Jumunjin & 5.4 & 21.2 & 10.9 & 19.9 & 30.2 & 33.8 & 30.3 & 33.8 \\
\hline Donghae & 6.8 & 22.9 & 12.7 & 18.3 & 30.1 & 34.2 & 32.5 & 33.0 \\
\hline Uljin & 9.2 & 22.9 & 22.6 & 22.6 & 31.2 & 34.4 & 32.9 & 32.9 \\
\hline Pohang & 9.9 & 23.5 & 9.9 & 23.5 & 22.0 & 34.4 & 22.0 & 34.4 \\
\hline Ulsan & 10.2 & 23.8 & 10.9 & 19.4 & 30.2 & 34.4 & 33.8 & 34.2 \\
\hline Busan & 10.5 & 23.5 & 12.7 & 20.9 & 23.2 & 34.3 & 29.7 & 34.2 \\
\hline Dadaepo & 7.3 & 23.1 & 19.4 & 21.4 & 26.3 & 33.9 & 26.3 & 32.3 \\
\hline Jinhae & 5.9 & 23.8 & 5.9 & 22.4 & 22.8 & 33.6 & 24.6 & 33.6 \\
\hline Masan & 5.6 & 24.0 & 7.4 & 7.4 & 9.9 & 33.0 & 31.3 & 31.3 \\
\hline Tongyoung & 1.1 & 22.3 & 22.3 & 22.3 & 21.8 & 33.4 & 29.2 & 29.2 \\
\hline Yeosu & 4.4 & 26.4 & 8.9 & 23.9 & 27.1 & 33.6 & 27.1 & 23.9 \\
\hline Kwangyang & 7.4 & 27.1 & 27.1 & 27.1 & 0.1 & 33.2 & 13.3 & 13.3 \\
\hline Goheung & 2.3 & 25.4 & 5.9 & 12.1 & 19.4 & 34.0 & 31.4 & 33.4 \\
\hline Jangheung & 3.8 & 24.7 & NA & NA & 26.4 & 33.1 & NA & NA \\
\hline Ansan & 1.7 & 25.6 & 1.7 & 8.8 & 27.2 & 34.3 & 30.9 & 33.6 \\
\hline Dangjin & 0.2 & 28.0 & 0.2 & 10.9 & 24.7 & 32.5 & 30.8 & 32.0 \\
\hline Mageompo & 1.9 & 23.2 & 1.9 & 23.2 & 31.0 & 35.6 & 31.0 & 34.2 \\
\hline Seocheon & 0.2 & 25.6 & 7.3 & 7.3 & 19.5 & 34.5 & 31.7 & 31.7 \\
\hline Kunsan & 1.8 & 23.8 & 7.9 & 23.8 & 29.3 & 33.9 & 29.3 & 32.0 \\
\hline Buan & 2.2 & 25.0 & 8.3 & 25.0 & 11.5 & 34.1 & 29.2 & 31.2 \\
\hline Mokpo & 5.0 & 25.8 & 25.4 & 25.4 & 9.6 & 33.6 & 30.0 & 30.0 \\
\hline Aewol & 12.1 & 24.3 & 12.5 & 23.5 & 22.7 & 33.1 & 23.6 & 32.3 \\
\hline Gosan & 11.3 & 24.5 & 11.3 & 11.3 & 29.7 & 34.4 & 34.4 & 34.4 \\
\hline Seogwipo & 14.8 & 24.2 & 20.4 & 22.2 & 17.5 & 33.0 & 17.5 & 30.1 \\
\hline Wimi & 14.0 & 23.6 & 15.9 & 21.7 & 20.8 & 33.8 & 20.8 & 30.0 \\
\hline Seongsan & 11.5 & 25.5 & 20.4 & 20.4 & 30.4 & 34.3 & 32.3 & 32.3 \\
\hline Gimnyeong & 10.8 & 24.5 & NA & NA & 20.0 & 31.9 & NA & NA \\
\hline
\end{tabular}

NA, not available.

Table 6. The abundance (cells $\mathrm{mL}^{-1}$ ) of Heterocapsa minima at each station from January 2016 to October 2018, quantified using qPCR method

\begin{tabular}{|c|c|c|c|c|c|c|c|c|c|c|c|c|c|c|}
\hline \multirow{2}{*}{ St. } & \multirow{2}{*}{ Name } & \multicolumn{5}{|c|}{2016} & \multicolumn{3}{|c|}{2017} & \multicolumn{4}{|c|}{2018} & \multirow{2}{*}{ Max } \\
\hline & & Jan & Mar & Jul & Oct & Dec & Mar & Jul & Oct & Jan & Mar & Jul & Oct & \\
\hline SC & Sokcho & - & - & - & 0.6 & NA & - & 0.2 & - & - & - & - & - & 0.6 \\
\hline JMJ & Jumunjin & - & - & - & - & 23.0 & - & 0.1 & - & - & - & 2.7 & - & 23.0 \\
\hline $\mathrm{DH}$ & Donghae & - & - & - & - & $<0.1$ & - & - & $<0.1$ & - & - & - & - & $<0.1$ \\
\hline UJ & Uljin & - & - & - & - & - & - & 0.3 & - & - & - & - & - & 0.3 \\
\hline $\mathrm{PH}$ & Pohang & - & - & 0.6 & - & 0.2 & - & 0.3 & - & $<0.1$ & - & 0.2 & - & 0.6 \\
\hline US & Ulsan & $<0.1$ & - & 1.7 & - & - & - & 24.8 & - & - & - & - & - & 24.8 \\
\hline BS & Busan & - & - & 5.9 & - & - & - & 1.2 & - & - & $<0.1$ & 0.2 & - & 5.9 \\
\hline DDP & Dadaepo & - & - & 0.1 & - & - & - & 0.6 & - & - & - & - & - & 0.6 \\
\hline $\mathrm{JH}$ & Jinhae & - & - & - & $<0.1$ & $<0.1$ & - & - & $<0.1$ & $<0.1$ & - & - & - & $<0.1$ \\
\hline MS & Masan & $<0.1$ & - & - & - & - & - & - & - & - & - & - & - & $<0.1$ \\
\hline TY & Tongyoung & - & - & - & $<0.1$ & - & - & - & - & - & - & - & - & $<0.1$ \\
\hline YS & Yeosu & - & - & $<0.1$ & - & - & $<0.1$ & - & - & - & $<0.1$ & - & $<0.1$ & $<0.1$ \\
\hline $\mathrm{KY}$ & Kwangyang & - & - & $<0.1$ & - & - & - & - & - & - & - & - & - & $<0.1$ \\
\hline GH & Goheung & - & $<0.1$ & - & - & $<0.1$ & - & - & - & - & - & - & - & $<0.1$ \\
\hline JAH & Jangheung & - & - & - & - & - & - & - & - & - & - & - & - & - \\
\hline AS & Ansan & $<0.1$ & - & - & - & $<0.1$ & - & - & - & $<0.1$ & - & - & - & $<0.1$ \\
\hline DAJ & Dangjin & - & $<0.1$ & - & - & - & - & - & - & $<0.1$ & $<0.1$ & - & - & $<0.1$ \\
\hline MGP & Mageompo & - & - & 0.4 & - & $<0.1$ & - & 0.6 & - & $<0.1$ & - & - & - & 0.6 \\
\hline SCN & Seocheon & - & - & - & - & $<0.1$ & - & - & - & - & - & - & - & $<0.1$ \\
\hline KS & Kunsan & - & $<0.1$ & 0.9 & $<0.1$ & $<0.1$ & - & 7.4 & - & - & - & - & - & 7.4 \\
\hline BA & Buan & - & - & - & - & - & $<0.1$ & 44.4 & - & - & - & - & - & 44.4 \\
\hline MP & Mokpo & - & - & - & - & - & - & 0.3 & - & - & - & - & - & 0.3 \\
\hline AW & Aewol & $<0.1$ & - & 1.7 & $<0.1$ & - & - & - & - & - & - & - & - & 1.7 \\
\hline GS & Gosan & NA & NA & NA & NA & NA & - & - & - & $<0.1$ & - & - & - & $<0.1$ \\
\hline SGP & Seogwipo & - & - & 9.8 & - & - & - & 0.3 & - & - & - & - & - & 9.8 \\
\hline WM & Wimi & - & $<0.1$ & 0.1 & - & - & - & 1.2 & - & - & - & - & - & 1.2 \\
\hline SS & Seongsan & - & - & 0.2 & - & - & - & - & - & - & - & - & - & 0.2 \\
\hline GN & Gimnyeong & NA & NA & NA & NA & NA & - & - & - & - & - & - & - & - \\
\hline
\end{tabular}

qPCR, quantitative real-time polymerase chain reaction; St., station; Max, maximum abundance at each station (cells $\mathrm{mL}^{-1}$ ); $<0.1$, cells of $H$. minima were detected, but the abundance was $<0.1$ cells $\mathrm{mL}^{-1}$; - , not detected; $\mathrm{NA}$, samples were not available. 


\section{Morphology of the Korean strain of Heterocapsa minima}

The shape of the Korean strain H. minima HMMJ1604 is very similar to that of the Irish strain H. minima JK2 (Table 2). When cells are examined using light microscopy (LM), the mean cell length and width of the Korean strain (9.5 and $6.9 \mu \mathrm{m}$, respectively) are smaller than those of the Irish strain (11.8 and $8.1 \mu \mathrm{m}$, respectively), but the ranges of the cell length and width of these two strains overlap (Table 2). Furthermore, when cells are examined using SEM, the mean cell length and width of the Korean strain (8.4 and $6.2 \mu \mathrm{m}$, respectively) are smaller than those of the Irish strain (10.2 and $7.1 \mu \mathrm{m}$, respectively), but the ranges of the cell length and width of these two strains also overlap (Table 2). Moreover, the mean cell length and width of the Korean strain are similar to those of the cells collected from the Celtic Sea (8.7 and 6.1 $\mu \mathrm{m}$, respectively). Therefore, the ranges of the cell length and width of the LM examined cells of $H$. minima collected from the Korean and Irish waters are 7.0-13.0 and 5.4-9.1 $\mu \mathrm{m}$, respectively, but those of SEM examined cells located from three locations are 7.3-12.9 and 5.2-9.0 $\mu \mathrm{m}$, respectively.

A difference was observed in the number of pores in the apical pore plate (Po) between the Korean (H. minima HMMJ1604) and the Irish (H. minima JK2) strains (Table 2); the Korean strain has five pores in the Po plate, whereas the Irish strain has six pores. However, Pomroy (1989) did not reported the number of pores in the Po of the cells from the Celtic Sea. Thus, it is worthwhile to investigate the number of pores in the Po of $H$. minima cells collected from other locations to determine whether the number of pores is variable among H. minima strains or cells obtained from different locations.

Salas et al. (2014) reported the presence of the scales as well as the hinge plate of the Irish strain H. minima JK2; these findings were not reported by Pomroy (1989). Furthermore, we observed the scales and also the hinge plate in the Korean strain of H. minima HMMJ1604. Thus, the present study confirms the presence of the scales and also the hinge plate in $H$. minima. As Salas et al. (2014) suggested, these features can be used to differentiate $H$. minima from the other species in the genus.

\section{Molecular characterization of the Korean strain of Heterocapsa minima}

Prior to the present study, there was only one H. minima strain (i.e., the Irish strain H. minima JK2) for which the rDNA sequences were available. In the phylogenetic tree based on the LSU sequences, $H$. minima JK2 was located in the basal position of the clade consisting of $H$. rotundata strains (Salas et al. 2014). Furthermore, in the phylogenetic tree based on ITS sequences, $H$. minima JK2 formed a clade with the endosymbiotic Heterocapsa sp., a symbiont of the acantharian Acanthochiasma sp., which is divergent from the clade of the strains of Heterocapsa arctica subspecies (Salas et al. 2014). The sequences of the LSU and ITS regions of the Korean stain H. minima HMMJ1604 are identical to that of the Irish strain. When the Korean strain is included, the Korean and Irish strains form a clade, which is clearly divergent from the clade of the strains of $H$. rotundata or $H$. arctica. Thus, the results of the present study confirm uniqueness of the rDNA sequence of $H$. minima.

\section{Distribution of Heterocapsa minima in Korean waters}

Prior to the present study, a few studies have reported the abundance of $H$. minima (Pomroy 1989, Iriarte et al. 2003); these studies quantified the abundance of H. minima using light microscopy after fixing cells with fixatives in the water samples collected from the Celtic Sea in four seasons and Bay of Biscay in one month. In the present study, H. minima was found all seasons in the Korean waters from 2016 to 2018, as in Celtic Sea in which this species was found all samples from July 1982 to October 1983 (Pomroy 1989, this study). The maximum abundance (44.4 cells $\mathrm{mL}^{-1}$ ) of $H$. minima in the Korean waters in the study period is higher than that in the Celtic Sea from July 1982 to October 1983 (9.2 cells $\mathrm{mL}^{-1}$ ), but slightly lower than that that in the Celtic Sea during a bloom caused by mixed phytoplankton species, including H. minima, in May 1986 (62.4 cells $\mathrm{mL}^{-1}$ ). Therefore, the maximum abundance of $H$. minima in the Korean waters is comparable to that in the Celtic Sea. The maximum abundances of H. minima in the Korean waters and the Celtic Sea were obtained in July and August / May, respectively. Thus, $H$. minima may be present all the seasons, but is abundant in the spring-summer. However, the maximum abundance of $H$. minima in the Korean waters is much higher than that in Bay of Biscay from 3rd to 17th of May 2001 (1.1 cells $\mathrm{mL}^{-1}$ ) (Iriarte et al. 2003). Fewer sampling seasons and fewer stations in the study of Iriarte et al. (2003) might be partially responsible for the lower maximum abundance in Bay of Biscay compared to the Korean waters.

The latitude at which the Korean strain of $H$. mini- 
$m a$ was found $\left(33^{\circ} 27^{\prime} \mathrm{N}-38^{\circ} 12^{\prime} \mathrm{N}\right)$ is lower than that at which the other strains of $H$. minima were found $\left(43^{\circ} 15^{\prime}\right.$ N-51 $1^{\circ} 39^{\prime} \mathrm{N}$ ) (Pomroy 1989, Iriarte et al. 2003, Salas et al. 2014). Thus, this study extends the latitudinal distribution of $H$. minima. The range of the surface water temperature at the stations where the Korean strain of $H$. minima were detected $\left(0.2-27.1^{\circ} \mathrm{C}\right)$ is wider than that in Celtic Sea from July 1982 to August 1983 (approximately $9-20^{\circ} \mathrm{C}$ ) and Bay of Biscay during May 2001 (approximately $12-18^{\circ} \mathrm{C}$ ) (Joint and Pomroy 1983, 1988, Joint et al. 1986, Pomroy 1989, Iriarte et al. 2003). The results of the present study suggest that $H$. minima is present at a wide range of water temperatures, including very low temperature in temperate regions. The surface water temperature at which the maximum abundance of $H$. minima was obtained in the Korean waters in $2016-2018$ was $25.0^{\circ} \mathrm{C}$, while that in Celtic Sea in $1982-1983$ is $20^{\circ} \mathrm{C}$. However, the water temperature at which the maximum abundance of H. minima was obtained in the Celtic Sea in May 1986 was not reported (Joint et al. 1986, Pomroy 1989). The surface water temperature in Celtic Sea in May 1984 was approximately $10-11^{\circ} \mathrm{C}$. Thus, $H$. minima can be abundant when water temperature is $10-25^{\circ} \mathrm{C}$. Meanwhile, the range of the water temperatures at the stations where the abundance of the Korean strain was higher than 1.0 cells $\mathrm{mL}^{-1}\left(10.9-25.0^{\circ} \mathrm{C}\right)$ become considerably narrower than detected. Thus, $H$. minima might survive at a wide range of water temperatures, but becomes abundant at moderate temperatures. To better understand the global and nationwide distribution of H. minima in one country, the quantification of its abundance or detection in the other seas and in waters off other countries is needed.

\section{ACKNOWLEDGEMENTS}

We thank An Suk Lim, Kyung Ha Lee, Se Hyeon Jang, and Eun Young Yoon, for technical support. This research was supported by the Useful Dinoflagellate program of Korea Institute of Marine Science and Technology Promotion (KIMST) funded by the Ministry of Oceans and Fisheries (MOF) and Management of marine organisms causing ecological disturbance and harmful effect Program of KIMST, the National Research Foundation (NRF) funded by the Ministry of Science and ICT (NRF-2015M1A5A1041806; NRF-2017R1E1A1A01074419) award to HJJ.

\section{REFERENCES}

Adolf, J. E., Bachvaroff, T. R., Deeds, J. R. \& Place, A. R. 2015. Ichthyotoxic Karlodinium veneficum (Ballantine) J Larsen in the upper Swan River estuary (Western Australia): ecological conditions leading to a fish kill. Harmful Algae 48:83-93.

Anderson, D. M., Alpermann, T. J., Cembella, A. D., Collos, Y., Masseret, E. \& Montresor, M. 2012. The globally distributed genus Alexandrium: multifaceted roles in marine ecosystems and impacts on human health. Harmful Algae 14:10-35.

Balech, E. 1988. Los dinoflagelados del Atlántico sudoccidental. Publicaciones Especiales Instituto Español de Oceanografia. Vol. 1. Ministerio de Agricultura Pesca y Alimentación, Secretaria General Técnica, Madrid, 310 pp.

Braarud, T. \& Pappas, I. 1951. Experimental studies on the dinoflagellate Peridinium triquetrum (Ehrb.) Lebour. Avhandlinger utgitt av Det Norske Videnskaps-Akademi i Oslo. I. Matematisk-Naturvidenskapelig Klasse, No. 2. Komm. Dybwaad, Oslo, pp. 1-23.

Burkholder, J. M., Glibert, P. M. \& Skelton, H. M. 2008. Mixotrophy, a major mode of nutrition for harmful algal species in eutrophic waters. Harmful Algae 8:77-93.

Carstensen, J., Klais, R. \& Cloern, J. E. 2015. Phytoplankton blooms in estuarine and coastal waters: seasonal patterns and key species. Estuar. Coast. Shelf Sci. 162:98109.

Flynn, K. J., Stoecker, D. K., Mitra, A., Raven, J. A., Glibert, P. M., Hansen, P. J., Granéli, E. \& Burkholder, J. M. 2013. Misuse of the phytoplankton-zooplankton dichotomy: the need to assign organisms as mixotrophs within plankton functional types. J. Plankton Res. 35:3-11.

Giovannoni, S. J., DeLong, E. F., Olsen, G. J. \& Pace, N. R. 1988. Phylogenetic group-specific oligodeoxynucleotide probes for identification of single microbial cells. J. Bacteriol. 170:720-726.

Glibert, P. M., Burkholder, J. M. \& Kana, T. M. 2012. Recent insights about relationships between nutrient availability, forms, and stoichiometry, and the distribution, ecophysiology, and food web effects of pelagic and benthic Prorocentrum species. Harmful Algae 14:231-259.

Grontved, J. \& Seidenfaden, G. 1938. The phytoplankton of the waters west of Greenland. Medd. Gronl. 82:1-380.

Guiry, M. D. \& Guiry, G. M. 2019. AlgaeBase. World-wide electronic publication, National University of Ireland, Galway. Available from: http://www.algaebase.org. Accessed Feb 7, 2019.

Hansen, G. 1989. Ultrastructure and morphogenesis of 
scales in Katodinium rotundatum (Lohmann) Loeblich (Dinophyceae). Phycologia 28:385-394.

Hansen, G. 1995. Analysis of the thecal plate pattern in the dinoflagellate Heterocapsa rotundata (Lohmann) comb. nov. (= Katodinium rotundatum (Lohmann) Loeblich). Phycologia 34:166-170.

Hansen, P. J. 2011. The role of photosynthesis and food uptake for the growth of marine mixotrophic dinoflagellates. J. Eukaryot. Microbiol. 58:203-214.

Horiguchi, T. 1995. Heterocapsa circularisquama sp. nov. (Peridiniales, Dinophyceae): a new marine dinoflagellate causing mass mortality of bivalves in Japan. Phycol. Res. 43:129-136.

Iriarte, A., Madariaga, I., Revilla, M. \& Sarobe, A. 2003. Shortterm variability in microbial food web dynamics in a shallow tidal estuary. Aquat. Microb. Ecol. 31:145-161.

Iwataki, M. 2008. Taxonomy and identification of the armored dinoflagellate genus Heterocapsa (Peridiniales, Dinophyceae). Plankton Benthos Res. 3:135-142.

Iwataki, M., Kawami, H., Van Nguyen, N., Luong, Q. D., Ton, T. P., Fukuyo, Y. \& Matsuoka, K. 2009. Cellular and body scale morphology of Heterocapsa huensis sp. nov. (Peridiniales, Dinophyceae) found in Hue, Vietnam. Phycol. Res. 57:87-93.

Iwataki, M., Takayama, H., Matsuoka, K. \& Fukuyo, Y. 2002. Heterocapsa lanceolata sp. nov. and Heterocapsa horiguchii sp. nov. (Peridiniales, Dinophyceae), two new marine dinoflagellates from coastal Japan. Phycologia 41:470-479

Jeong, H. J., Lee, K. H., Yoo, Y. D., Kang, N. S., Song, J. Y., Kim, T. H., Seong, K. A., Kim, J. S. \& Potvin, E. 2018. Effects of light intensity, temperature, and salinity on the growth and ingestion rates of the red-tide mixotrophic dinoflagellate Paragymnodinium shiwhaense. Harmful Algae 80:46-54.

Jeong, H. J., Lim, A. S., Franks, P. J. S., Lee, K. H., Kim, J. H., Kang, N. S., Lee, M. J., Jang, S. H., Lee, S. Y., Yoon, E. Y., Park, J. Y., Yoo, Y. D., Seong, K. A., Kwon, J. E. \& Jang, T. Y. 2015. A hierarchy of conceptual models of red-tide generation: nutrition, behavior, and biological interactions. Harmful Algae 47:97-115.

Jeong, H. J., Lim, A. S., Lee, K., Lee, M. J., Seong, K. A., Kang, N. S., Jang, S. H., Lee, K. H., Lee, S. Y., Kim, M. O., Kim, J. H., Kwon, J. E., Kang, H. C., Kim, J. S., Yih, W., Shin, K., Jang, P. K., Ryu, J. -H., Kim, S. Y., Park, J. Y. \& Kim, K. Y. 2017. Ichthyotoxic Cochlodinium polykrikoides red tides offshore in the South Sea, Korea in 2014: I. Temporal variations in three-dimensional distributions of red-tide organisms and environmental factors. Algae 32:101-130.
Jeong, H. J., Yoo, Y. D., Kim, J. S., Seong, K. A., Kang, N. S. \& Kim, T. H. 2010. Growth, feeding, and ecological roles of the mixotrophic and heterotrophic dinoflagellates in marine planktonic food webs. Ocean Sci. J. 45:65-91.

Jeong, H. J., Yoo, Y. D., Lee, K. H., Kim, T. H., Seong, K. A., Kang, N. S., Lee, S. Y., Kim, J. S., Kim, S. \&Yih, W. H. 2013. Red tides in Masan Bay, Korea in 2004-2005: I. Daily variations in the abundance of red-tide organisms and environmental factors. Harmful Algae 30(Suppl. 1):S75-S88.

Jeong, H. J., Yoo, Y. D., Park, J. Y., Song, J. Y., Kim, S. T., Lee, S. H., Kim, K. Y. \& Yih, W. H. 2005. Feeding by the phototrophic red-tide dinoflagellates: five species newly revealed and six species previously known to be mixotrophic. Aquat. Microb. Ecol. 40:133-150.

Johnson, M. D. 2015. Inducible mixotrophy in the dinoflagellate Prorocentrum minimum. J. Eukaryot. Microbiol. 62:431-443.

Joint, I. R., Owens, N. J. P. \& Pomroy, A. J. 1986. Seasonal production of photosynthetic picoplankton and nanoplankton in the Celtic Sea. Mar. Ecol. Prog. Ser. 28:251258.

Joint, I. R. \& Pomroy, A. J. 1983. Production of picoplankton and small nanoplankton in the Celtic Sea. Mar. Biol. 77:19-27.

Joint, I. R. \& Pomroy, A. J. 1988. Allometric estimation of the productivity of phytoplankton assemblages. Mar. Ecol. Prog. Ser. 47:161-168.

Kibbe, W. A. 2007. OligoCalc: an online oligonucleotide properties calculator. Nucleic Acids Res. 35(Suppl 2):W43W46.

Kwon, J. E. 2018. Feeding by the heterotrophic nanoflagellate Katablepharis japonica on red-tide organisms and interactions between the phototrophic dinoflagellate Heterocapsa minima and heterotrophic protists. M.S. dissertation, Seoul National University, Seoul, Korea, $116 \mathrm{pp}$.

Lebour, M. V. 1925. The Dinoflagellates of the Northern Seas. Marine Biological Association of the United Kingdom, Plymouth, $250 \mathrm{pp}$.

Lee, M. J., Jeong, H. J., Kim, J. S., Jang, K. K., Kang, N. S., Jang, S. H., Lee, H. B., Lee, S. B., Kim, H. S. \& Choi, C. H. $2017 a$. Ichthyotoxic Cochlodinium polykrikoides red tides offshore in the South Sea, Korea in 2014: III. Metazooplankton and their grazing impacts on red-tide organisms and heterotrophic protists. Algae 32:285-308.

Lee, S. Y., Jeong, H. J., Seong, K. A., Lim, A. S., Kim, J. H., Lee, K. H., Lee, M. J. \& Jang, S. H. 2017b. Improved real-time PCR method for quantification of the abundance of all known ribotypes of the ichthyotoxic dinoflagellate Cochlodinium polykrikoides by comparing 4 different 
preparation methods. Harmful Algae 63:23-31.

Lim, A. S., Jeong, H. J., Seong, K. A., Lee, M. J., Kang, N. S., Jang, S. H., Lee, K. H., Park, J. Y., Jang, T. Y. \& Yoo, Y. D. 2017. Ichthyotoxic Cochlodinium polykrikoides red tides offshore in the South Sea, Korea in 2014: II. Heterotrophic protists and their grazing impacts on redtide organisms. Algae 32:199-222.

Litaker, R. W., Vandersea, M. W., Kibler, S. R., Reece, K. S., Stokes, N. A., Steidinger, K. A., Millie, D. F., Bendis, B. J., Pigg, R. J. \& Tester, P. A. 2003. Identification of Pfiesteria piscicida (Dinophyceae) and Pfiesteria-like organisms using internal transcribed spacer-specific PCR assays. J. Phycol. 39:754-761.

Lohmann, H. 1908. Untersuchungen zur Feststellung des vollständigen Gehaltes des Meeres an Plankton. Wiss. Meeresunters. Abt. Kiel 10:129-370.

Matsuyama, Y. 1999. Harmful effect of dinoflagellate Heterocapsa circularisquama on shellfish aquaculture in Japan. JARQ 33:283-293.

Matsuyama, Y., Kimura, A., Fujii, H., Takayama, H. \& Uchida, T. 1997. Occurrence of a Heterocapsa circularisquama red tide and subsequent damages to shellfish in western Hiroshima Bay, Seto Inland Sea, Japan in 1995. Bull. Nansei. Natl. Fish. Res. Inst. 30:189-207.

Matsuyama, Y., Nagai, K., Mizuguchi, T., Fujiwara, M., Ishimura, M., Yamaguchi, M., Uchida, T. \& Honjo, T. 1995. Ecological features and mass mortality of pearl oysters during red tides of Heterocapsa sp. in Ago Bay in 1992. Nippon Suisan Gakk. 61:35-41.

Menden-Deuer, S. \& Montalbano, A. L. 2015. Bloom formation potential in the harmful dinoflagellate Akashiwo sanguinea: clues from movement behaviors and growth characteristics. Harmful Algae 47:75-85.

Nagai, K., Matsuyama, Y., Uchida, T., Yamaguchi, M., Ishimura, M., Nishimura, A., Akamatsu, S. \& Honjo, T. 1996. Toxicity and $\mathrm{LD}_{50}$ levels of the red tide dinoflagellate Heterocapsa circularisquama on juvenile pearl oysters. Aquaculture 144:149-154.

Paulsen, O. 1908. XVIII. Peridiniales. In Brandt, K. \& Apstein, C. (Eds.) Nordisches Plankton. Lipsius and Tischer, Kiel, pp. 1-124.

Place, A. R., Bowers, H. A., Bachvaroff, T. R., Adolf, J. E., Deeds, J. R. \& Sheng, J. 2012. Karlodinium veneficum: the little dinoflagellate with a big bite. Harmful Algae 14:179-195.

Pomroy, A. J. 1989. Scanning electron microscopy of Heterocapsa minima sp. nov. (Dinophyceae) and its seasonal distribution in the Celtic Sea. Br. Phycol. J. 24:131-135.
Ronquist, F. \& Huelsenbeck, J. P. 2003. MRBAYES 3: Bayesian phylogenetic inference under mixed models. Bioinformatics 19:1572-1574.

Salas, R., Tillmann, U. \& Kavanagh, S. 2014. Morphological and molecular characterization of the small armoured dinoflagellate Heterocapsa minima (Peridiniales, Dinophyceae). Eur. J. Phycol. 49:413-428.

Scholin, C. A., Gulland, F., Doucette, G. J., Benson, S., Busman, M., Chavez, F. P., Cordaro, J., DeLong, R., De Vogelaere, A., Harvey, J., Haulena, M., Lefebvre, K., Lipscomb, T., Loscutoff, S., Lowenstine, L. J., Marin, R. 3rd, Miller, P. E., McLellan, W. A., Moeller, P. D. R., Powell, C. L., Rowles, T., Silvagni, P., Silver, M., Spraker, T., Trainer, V. \& Van Dolah, F. M. 2000. Mortality of sea lions along the central California coast linked to a toxic diatom bloom. Nature 403:80-84.

Scholin, C. A., Herzog, M., Sogin, M. \& Anderson, D. M. 1994. Identification of group- and strain-specific genetic markers for globally distributed Alexandrium (Dinophyceae). II. Sequence analysis of a fragment of the LSU rRNA gene. J. Phycol. 30:999-1011.

Shumway, S. E., Allen, S. M. \& Boersma, P. D. 2003. Marine birds and harmful algal blooms: sporadic victims or under-reported events? Harmful Algae 2:1-17.

Stamatakis, A. 2006. RAxML-VI-HPC: maximum likelihoodbased phylogenetic analyses with thousands of taxa and mixed models. Bioinformatics 22:2688-2690.

Stein, F. 1883. Der Organismus der Infusionsthiere. III. Abt. Der Organismus der Arthrodelen Flagellaten nach eigenen Forschungen in systematischer Reihenfolge bearbeitet. II. Hälfte. Einleitung und Erklärung der Abbildungen. W. Engelmann, Leipzig, pp. 1-30.

Stoecker, D. K., Hansen, P. J., Caron, D. A. \& Mitra, A. 2017. Mixotrophy in the marine plankton. Ann. Rev. Mar. Sci. 9:311-335.

Tamura, K., Dudley, J., Nei, M. \& Kumar, S. 2007. MEGA4: molecular evolutionary genetics analysis (MEGA) software version 4.0. Mol. Biol. Evol. 24:1596-1599.

Tillmann, U. 2004. Interactions between planktonic microalgae and protozoan grazers. J. Eukaryot. Microbiol. 51:156-168.

Tillmann, U., Hoppenrath, M., Gottschling, M., Kusber, W. H. \& Elbrächter, M. 2017. Plate pattern clarification of the marine dinophyte Heterocapsa triquetra sensu Stein (Dinophyceae) collected at the Kiel Fjord (Germany). J. Phycol. 53:1305-1324. 